\title{
НАВЧАННЯ НА РОБОЧОМУ МІСЦІ ЛІКАРІВ І ПРОВІЗОРІВ - АНАЛІЗ МОЖЛИВОСТЕЙ
}

\author{
О. П. Мінцер, О. В. Голяновський, С. В. Денисенко, Тахере Гасемі \\ Національна медична академія післядипломної освіти імені П. Л. Шупика

\begin{abstract}
Найважливішу роль у роботі сучасного університету розпочинає грати функція трансферу знань. Вона покликана
\end{abstract} \\ забезпечити передачу та трансформацію знань, включаючи технології, досвід та навички тим, хто навчається, \\ протягом всього життя, особливо під час безперервного професійного розвитку. Розглянуті модулі нової системи \\ постійного навчання фахівців.
}

Ключові слова: системи передачі знань, безперервний професійний розвиток, трансфер знань, інноваційне суспільство, інтеграція знань.

\section{ОБУЧЕНИЕ НА РАБОЧЕМ МЕСТЕ ВРАЧЕЙ И ПРОВИЗОРОВ - АНАЛИЗ ВОЗМОЖНОСТЕЙ}

\author{
О. П. Минцер, О. В. Голяновский, С. В. Денисенко, Тахере Гасеми \\ Национальная \\ медицинская академия \\ последипломного \\ образования \\ имени \\ п. Л. \\ Шупика
}

Важнейшую роль в работе современного университета начинает играть функция трансфера знаний. Она призвана обеспечить передачу и трансформацию знаний, включая технологии, опыт и навыки обучаемых на протяжении всей жизни, особенно во время непрерывного профессионального развития. Рассмотрены модули новой системы постоянного обучения специалистов.

Ключевые слова: системы передачи знаний, непрерывное профессиональное развитие, инновационное общество, интеграция знаний.

\section{TRAINING OF DOCTORS AND PHARMACISTS ON THE WORKPLACE - ANALYSIS OF OF PPORTUNITIES

\author{
O. P. Mintser, O. V. Golyanovskyj, S. V. Denysenko, Tahereh Ghasemi \\ National Medical Academy of Post-Graduate Education named after P. L. Shupyk
}

The knowledge transfer function appears to be the most important in the modern university. It is purposed to ensure the transfer and transformation of knowledge, including technology, experience and skills by learners, especially in continuous professional development. Modules of a new system of continuous learning of professionals are considered.

Key words: systems of knowledge transfer, continuous professional development, innovative society, integration of knowledge.

Вступ. Визначення сучасного суспільства як «інноваційного» відображає принципово нову його якість, що пов'язана з необхідністю максимального прискорення науково-технічного розвитку. Останній, в свою чергу, формується рівнем освітніх організацій, перш за все, університетами.

Функціонування інноваційного суспільства здійснюється за рахунок інтенсивного та масштабного передавання нових знань, що згенеровані в університетах, включаючи технології в різних (природничо-наукових, технічних і соціально-гуманітарних) галузях діяльності. Для нього запроваджено новий термін «інноваційний університет».

Зрозуміло, університет не є єдиним місцем з виготовлення та розповсюдження знань. Корпоративні навчальні заклади, науково-дослідні інститути також виробляють знання. Проте в центрі цієї діяльності має знаходитись університет як єдина організація, де здійснюється виробництво інтегрованих знань [1, 3, 4]. Зауважимо, що виробництво знань щонайменше не найважливіше завдання. Домогтися ефективного та коректного передавання знань (трансферу знань) 
до останнього часу було досить важко. Лише на сьогодні з'явився інструментарій, що дозволяє вирішити проблему маловартісного зв'язку як із суб'єктами навчання, так і з виробником знань. Цей інструментарій отримав назву «технологія навчання на робочому місці».

Метою роботи є визначення місця нової технології передавання знань - «навчання на робочому місці» в безперервному професійному розвитку лікарів і провізорів.

Результати та їх обговорення. Концептуальна основа «технології навчання на робочому місці» складається 3 трьох частин. Більша частина часу (до 70 \%) присвячується управлінню діями суб'єкта навчання дистанційними методами безпосередньо на робочому місці. Менша частина часу (як правило, не більше 20 \%) надається навчанню також на робочому місці з більш досвідченим співробітником. При цьому використовуються спеціальні дидактичні прийоми, наприклад, наставництво, коучінг, т'юторінг, тренінг тощо. Нарешті, останню частину робочого часу суб'єкт навчання витрачає на слухання лекцій, семінарів тощо. Саме завдяки такому розподілу часу подібна технологія отримала назву «70-20-10».

Перевагою підходу «70-20-10» та технологією «навчання на робочому місці» користуються, зокрема, великі університети, корпоративні університети, навчальні центри. Його розповсюдженню сприяє популярний у навчальному середовищі компетентністний підхід.

Зрозуміло, що компетенції розвиваються не відразу, над їх прогресом слід ретельно працювати. Саме тому навчання на робочому місці дозволяє використовувати час на роботі для відпрацювання окремих компетенцій.

Ще одна причина, яка сприяє розвитку цієї нової технології - потреба великої кількості населення в отриманні другої й навіть третьої освіти. Друга освіта отримала статус нового витка розвитку з проблеми навчання персоналу. Дійсно, історично так складалася ситуація, що підготовка та вдосконалення персоналу компаній, університетів, інших структур залишалася поза соціальною освітою. Саме тому для реалізації процесів навчання багато компаній звернулися до технологій «shared workplace» (колективне робоче місце).

Очевидно, що соціальне навчання не замінить традиційного, проте, воно забезпечить суттєве доповнення до звичних форм навчання принципами колективної роботи чи сумісної творчості.
Багато авторів визначають навчання на робочому місці як перспективну, швидку й ефективну методику професійного зростання фахівця.

Так, в проекті Training.com.uа надруковані результати опитування відвідувачів порталу щодо найбільш розповсюджуваних форм навчання персоналу в 2009 році. Вони показали, що більшість компаній використовували формат навчання на робочому місці. Це підтвердили до 33 \% опитаних. Зауважимо, що компанії неодноразово підтверджували, що подібна форма передавання знань найменш витратна. На другому місці за популярністю виявилися корпоративні тренінги (23,3\%). Суттєво менший відсоток опитаних користується відкритими тренінгами $(17,4$ \%), коучінгом та наставництвом (12,4 \%). На подив мала кількість респондентів відмітили змішане навчання $(8,8 \%)$ та дистанційне навчання (6 \%).

Нами запропоновано для трансферу знань використовувати комплекс програмних засобів, що включають технологію Lync Server 2010 (чи Адобе-акробат). Вона надає нові можливості підключення та комунікації для суб'єктів навчання під час безперервного професійного розвитку.

Система Lync 2010 об'єднує й уніфікує всі сучасні засоби комунікації, а також відеоконференцзв'язок. Усі ці види комунікацій доступні через єдиний інтерфейс та єдину серверну інфраструктуру. Серед інших можливостей можна назвати інтеграцію з серверами контролю місця положення слухача. Фактичне розміщення користувача можна відслідкувати за адресою підмережі, до котрої користувач підключений, або за найближчою точкою бездротового доступу.

Одночасно пропонується використовувати національний продукт - ПЗ «СВIT», розроблений Інститутом глобального інформаційного простору НАН України. Медичні та навчальні версії створювалися разом із співробітниками кафедри медичної інформатики Національної медичної академії післядипломної освіти імені П. Л. Шупика.

Принципово, нова освіта повинна базуватися на використанні декількох модулів. Найважливішими серед них вважаємо: 1. Системи розповсюдження (трансферу) інформації, наприклад, Lync Server 2010. 2. Системи швидкого пошуку необхідної літератури (наприклад, платформу Exalead). 3. Системи, що допомагають реалізувати завдання моніторингу навчання (портфоліо). 4. Комп'ютерні системи контролю знань, наприклад платформа MOODLE. 5. Системи індивідуалізованого адаптивного навчання, наприклад, система EduPro. 
Вже перший досвід багаточисленних відеоконференцзустрічей і конференцій показав, що сьогодні технологічно можливе підключення до навчання (лекції, семінари, консультування) тисяч тих, хто бажає отримати знання. Так, під час конференції "Багатоплодова вагітність" (Київ, 2011) нами було забезпечено вільне приєднання понад 1000 фахівців із України та зарубіжжя. Були задіяні 92 точки з'єднання з 75 міст України. Підкреслимо, що подібне з'єднання не потребує ніякого спеціального обладнання для користувача.

\section{Література}

1. Стронгин Р. Г. Университет как интегратор в обществе, основанном на знании / Р. Г. Стронгин, Г. А. Максимов, А. О. Грудзинский // Высшее образование в России. - 2006. - №> 1 . C. $15-27$.

2. «Группа восьми» об образовании // Высшее образование сегодня. - 2006. - №>1. - С. 15 - 27.
По суті, відкривається нова ера передавання професійних медичних знань і нової організації безперервного професійного розвитку лікарів і провізорів.

Висновки. 1. Сучасний трансфер знань - це система організації багатоканального та багаторівневого інтерфейсу між університетом і його зовнішнім оточенням, насамперед, з суб'єктами навчання та підприємством із високими технологіями.

2. Навчання на робочому місці та корпоративні тренінги займають лідируючі позиції серед найпоширеніших форматів навчання.

3. Всемирная конференция по высшему образованию 2009. Итоговое коммюнике // Высшее образование сегодня. - 2009. - №>8. - С. 13 - 17.

4. Грудзинский А.О. Трансфер знаний - функция инновационного университета / А. О. Грудзинский, А. Б. Бедный // Высшее образование в России. - 2009. - №9. - С. 66 - 71. 